\title{
Antibacterial Effects of Cissus welwitschii and Triumfetta welwitschii Extracts against Escherichia coli and Bacillus cereus
}

\author{
Batanai Moyo and Stanley Mukanganyama \\ Biomolecular Interactions Analyses Laboratory, Department of Biochemistry, University of Zimbabwe, P.O. Box MP167, \\ Mount Pleasant, Harare, Zimbabwe \\ Correspondence should be addressed to Stanley Mukanganyama; smukanganyama@medic.uz.ac.zw
}

Received 6 July 2015; Revised 22 September 2015; Accepted 19 October 2015

Academic Editor: Ramakrishna Nannapaneni

Copyright (C) 2015 B. Moyo and S. Mukanganyama. This is an open access article distributed under the Creative Commons Attribution License, which permits unrestricted use, distribution, and reproduction in any medium, provided the original work is properly cited.

\begin{abstract}
Antibiotic resistance has increased sharply, while the pace for the development of new antimicrobials has slowed down. Plants provide an alternative source for new drugs. This study aimed to screen extracts from Cissus welwitschii and Triumfetta welwitschii for antibacterial activity against Escherichia coli and Bacillus cereus. The tests conducted included a susceptibility determination test, analysis of the effect of T. welwitschii on cell wall integrity, and transport across the membrane. It was found that the T. welwitschii methanol extracts were more effective than the water extracts and had the lowest minimum inhibitory concentration and minimum bactericidal concentration at $0.125 \mathrm{mg} / \mathrm{mL}$ and $0.5 \mathrm{mg} / \mathrm{mL}$, respectively, against $E$. coli and B. cereus. The C. welwitschii extract caused the most drug accumulation in E. coli. In B. cereus, no significant drug accumulation was observed. Nucleic acid leakage in B. cereus and $E$. coli and protein leakage in E. coli were observed after exposure to the T. welwitschii extract. The extracts from T. welwitschii had greater antibacterial activity than the extracts from $C$. welwitschii. T. welwitschii may be a potential source of lead compounds for that could be developed into antibacterial agents.
\end{abstract}

\section{Introduction}

Antibiotic resistance has become a major problem worldwide in recent years. The unnecessary prescription of antibiotics to treat viral infections, incorrect prescriptions due to a lack of culturing to determine the exact cause of infection, patients not completing their antibiotic treatments, and the excessive use of antibiotics in stock feed are some of the causes of the increased selective pressures placed on bacteria by antibiotics, leading to resistance [1]. There has been a decrease in the development of antimicrobial agents by pharmaceutical companies [2] as their development is not as profitable as developing drugs that treat chronic and lifestyle diseases [3]. In the last four decades, only three new classes of antibiotics have been discovered which are lipopeptides, oxazolidinones, and streptogramins [4]. As most of the old and cheap antibiotics are no longer effective, the use of second or third line drugs has become necessary, and these may have side effects [5]. When patients are infected with organisms resistant to all available antimicrobials, surgery is required to remove the nidus of infection, increasing the risk of death [6]. Drug resistance is of particular concern among patients with compromised immunity [7]. Infectious diseases account for half of all deaths in tropical countries [8] and 90\% of infections are caused by bacteria [9].

Bacteria have the ability to acquire resistance mechanisms such as genes encoding enzymes such as $\beta$-lactamases, genes that alter the bacterial cell wall resulting in no binding site for the antimicrobial agent and efflux pumps through conjugation, translation, and transduction [10]. Efflux pumps are transport proteins involved in the extrusion of toxic substrates (including almost all classes of clinically relevant antibiotics) [9]. Efflux pumps either can be selective or can be multidrug efflux pumps, and the extrusion of antimicrobial agents via these efflux pumps is a major component of resistance [11]. Cells can use proton driven antiporters and/or ATP driven (ATP-binding cassette) transporters to expel drugs [12]. Efflux pump inhibitors can be used to restrict the efflux 
of antibiotics from bacterial cells, meaning that resistance to antibiotics such as ciprofloxacin can be reversed and drug resistance can be inhibited [13]. Examples of commonly used efflux pump inhibitors are verapamil and MC-207,110 [12]. As a result of antibiotic resistance, new antimicrobials that will either replace or be used with antibiotics are required.

In African countries, traditional medicines are used by approximately $80 \%$ of the population, while usage of alternative medicines in developed countries is increasing [14]. Traditional medicines are extensively incorporated into the public health system of some countries [15]. To date, studies have confirmed that some plant extracts can be used to treat infectious diseases caused by bacteria as they have antibacterial properties [16-18]. Studies have been conducted to determine the effects of plant extracts on the activity of antibiotics against resistant bacteria [7,9]. Plant extracts have been used to inhibit microbial growth in food and drinks [19].

Interest in herbal medicines has increased in recent years due to the fact that they are cheap, readily available, and effective, as well as the high cost of industrialized medicines, lack of access to healthcare, and the side effects caused by taking synthetic medicines [20]. Natural products offer a large diversity of chemical structures which often serve as lead molecules whose activities can be enhanced by manipulation through combinations with chemicals and by synthetic chemistry [21, 22]. Novel compounds from plants may not have the problem of antimicrobial resistance [21]. Natural plant extracts have been found to be an important source of secondary metabolites such as tannins, terpenoids, alkaloids, and flavonoids, which have been found in vitro to have antimicrobial properties [22]. Some plant extracts have also been classified as resistance modifiers because they can enhance antibiotic activity or reverse antibiotic resistance [22]. In Zimbabwe, plants have been used for centuries to treat various ailments. Examples are Vernonia adoensis leaves for the treatment of tuberculosis and Salons delagoense leaves and fruits for the treatment of scabies in children [23]. Aloe excelsa, Cymbopogon nardus, pepper, coconut milk, and coconut oil are some plants used for the preparation of ointments, lotions, and creams [24].

The aim of this study was to investigate the antibacterial properties of the aqueous and methanol extracts of Cissus welwitschii and Triumfetta welwitschii var. welwitschii. The genus Cissus contains 350 species and is found in tropical and subtropical locations [25]. Cissus is a member of the grape family Vitaceae [25]. C. welwitschii is found in tropical Africa, often on granite outcrops and termite mounds and in forests, semievergreen bushland, and woodland [26]. The plant is a vigorous grower, that is, $1.8-9 \mathrm{~m}$ long or shrubby, and has aerial roots [26]. C. welwitschii has hairless, cylindrical stems that are often spotted black and granular [26]. The plant has simple leaves and tendril, and is closely related to C. fragilis [27]. C. welwitschii is used traditionally in Zimbabwe for the treatment of cancer.

Triumfetta welwitschii var. welwitschii is a perennial herb that grows annual stems from a woody rootstock and usually flowers before the leaves develop [28]. The plant is a conspicuous species of burnt roadsides, grassland, and woodland [28]. Three varieties of T. welwitschii exist, namely, welwitschii, descampsii, and hirsuta [28]. In Zimbabwe, T. welwitschii is used to treat diarrhoea [29], suggesting that it has antibacterial effects. Microorganisms contribute to food spoilage and in turn diarrhoea, so treatment of diarrhoea using the T. welwitschii plant extract may indicate that the plant has antibacterial activity. In South Africa, a decoction of the tuber is mixed with milk and drunk as a fever remedy [30] suggesting that it has antipyretic effects.

Escherichia coli and Bacillus cereus were the two bacteria used in this study. Nonpathogenic strains of E. coli live in the human colon. However, several strains are important foodborne pathogens. Pathogenic strains include E. coli O157:H7 which was first discovered in 1982 [1]. This strain is found in meat products, unpasteurised fruit juices, fruits, vegetables, and untreated water and is known to cause haemolytic uremic syndrome [1]. E. coli O55, O111, and $\mathrm{O} 127$ have been associated with infant diarrhoea, while other strains have been associated with nosocomial infections in the skin, urinary tract, and surgical wounds [1]. E. coli strains resistant to drugs including penicillins and cephalosporins have been discovered [1].

$B$. cereus causes food poisoning and is especially problematic in starchy foods [1]. The emetic toxin produced by $B$. cereus has been associated with improperly stored boiled and fried rice (causes nausea and vomiting) while the diarrheal type is associated with a wider range of foods [1]. As B. cereus and $E$. coli cause very serious illnesses, new drugs are needed that can adequately manage the infections that they cause.

The plants used in traditional medicine are potential sources of antibacterial agents. Many plants used traditionally achieve good results, so studying these plants may give rise to new potent antimicrobials with different mechanisms of action. The results of this study can be used to either validate or invalidate the use of T. welwitschii and C. welwitschii in traditional medicine.

\section{Materials and Methods}

2.1. Chemicals. All chemicals and antibiotics used were purchased from Sigma-Aldrich, Steinheim, Germany, and were of analytical grade. The major chemicals and antibiotics used were methanol, for extractions, reserpine, an efflux pump inhibitor, rhodamine $6 \mathrm{G}$, a probe compound for the drug efflux assay, propidium iodide dye, used to stain nucleic acids, Bradford's Reagent for protein determination using the Bradford's assay, and the three antibiotics used in the study: ampicillin, kanamycin, and norfloxacin.

2.2. Plant Material. Cissus welwitschii and Triumfetta welwitschii were collected from Centenary $\left(16.8^{\circ} \mathrm{S}, 31.1167^{\circ} \mathrm{E}\right.$, and $1156 \mathrm{~m}$ above sea level), Mashonaland Central Province, Zimbabwe. The plants were identified and authenticated by Mr. Christopher Chapano, a botanist with the National Botanical and Herbarium Garden (Harare, Zimbabwe).

2.3. Preparation of Extracts. The dried leaves and roots of each plant were ground separately in a blender (Philips Co., Shanghai, China). To $10 \mathrm{~g}$ of plant material, either $100 \mathrm{~mL}$ 
of methanol or $200 \mathrm{~mL}$ of distilled water was added. Two hundred millilitres of distilled water was used as the mixture became viscous during stirring. The mixtures were stirred using a magnetic stirrer for 20 minutes. The methanol extracts were filtered using No. 1 Whatman filter paper, while the water extracts were filtered using mutton cloth. The filtrate was evaporated to dryness, collected, and stored at room temperature.

\subsection{Bacteria. Escherichia coli ATCC 11229 and Bacillus cereus} ATCC 11778 were used in this study. The bacteria were grown from glycerol stocks stored at $-33^{\circ} \mathrm{C}$. On nutrient agar plates, $25 \mu \mathrm{L}$ of bacteria was plated and grown overnight at $37^{\circ} \mathrm{C}$ in an incubator (Lab Design Engineering (Pty) Ltd., Maraisburg, South Africa). From the plates, 1 colony was inoculated into nutrient broth and grown overnight at $37^{\circ} \mathrm{C}$ with shaking at 160 revolutions per minutes (rpm) (Lab Companion, Jeio Tech, South Korea). The plates and bacterial culture tubes were stored at $4^{\circ} \mathrm{C}$. Fresh stocks were prepared for each assay.

\subsection{Determination of Antibacterial Activity Using the Agar} Disk Diffusion Method. Molten nutrient agar was inoculated with bacteria to a final concentration of $1 \times 10^{6} \mathrm{cfu} / \mathrm{mL}$. The agar was poured into petri dish plates and allowed to solidify. Stock solutions of C. welwitschii, T. welwitschii, and the antibiotic ampicillin were prepared to a concentration of $25 \mathrm{mg} / \mathrm{mL}$ by dissolving the plant extracts in the extracting solvent and ampicillin in distilled water. Filter paper disks measuring $6 \mathrm{~mm}$ in diameter were prepared. To each disk, $20 \mu \mathrm{L}$ of extract or antibiotic was added. The samples were prepared in quadruplicate. The disks were allowed to dry before being placed onto the plates impregnated with bacteria. The plates were stored at $4^{\circ} \mathrm{C}$ for two hours to allow the extracts and antibiotics to diffuse into the agar. The plates were incubated overnight at $37^{\circ} \mathrm{C}$. The diameters of the zones of inhibition were measured in millimetres.

\subsection{Minimum Inhibitory Concentration (MIC) and Minimum} Bactericidal Concentration (MBC). The MICs of the plant extracts and antibiotics against $B$. cereus and $E$. coli were determined using the broth dilution method. The assay was based on the method described by Eloff [31]. One in two serial dilutions of the extracts and antibiotics were prepared. For the plant extracts and ampicillin, the concentrations used ranged from $0.008 \mathrm{mg} / \mathrm{mL}$ to $4 \mathrm{mg} / \mathrm{mL}$, while, for kanamycin and norfloxacin, the concentrations used ranged from $1 \mu \mathrm{g} / \mathrm{mL}$ to $1 \mathrm{mg} / \mathrm{mL}$. One hundred microliters of the extracts and antibiotics was added to wells in microwell plates. To each well, $100 \mu \mathrm{L}$ of bacteria was added to achieve a final concentration of $1 \times 10^{6} \mathrm{cfu} / \mathrm{mL}$. Wells containing $200 \mu \mathrm{L}$ of broth only, $100 \mu \mathrm{L}$ of the extracts or antibiotics and $100 \mu \mathrm{L}$ of broth, and $100 \mu \mathrm{L}$ of broth and $100 \mu \mathrm{L}$ of bacteria were used as the controls. The plates were incubated at $37^{\circ} \mathrm{C}$ with shaking at 30 rpm overnight.

After incubation, the absorbance of the wells was measured at $600 \mathrm{~nm}$ using a microplate spectrophotometer (SpectraMaxPlus, Molecular Devices, Sunnyvale, USA).
To each well, $25 \mu \mathrm{L}$ of 3-(4,5-dimethylthiazol-2-yl)-2,5diphenyltetrazolium bromide (MTT) was then added. MTT turns dark blue (from yellow) in the presence of living cells [32]. The plates were incubated for 1 hour at $37^{\circ} \mathrm{C}$ at $30 \mathrm{rpm}$. The absorbance was measured at $570 \mathrm{~nm}$.

To determine the MBC, one loopful of the bacteria in the wells that contained the MIC was streaked, in duplicate, onto nutrient agar plates without antibiotics. The wells that contained extracts at one and two concentrations higher and one concentration lower than the MIC were also plated. The plates were incubated for 24 hours at $37^{\circ} \mathrm{C}$.

2.7. Effects of Plant Extracts on Drug Accumulation. The drug accumulation assay was used to determine the effects of the plant extracts on drug accumulation in E. coli and B. cereus. The method described by Chitemerere and Mukanganyama [23] was used with some modifications. The bacteria were grown overnight at $37^{\circ} \mathrm{C}$ in two separate flasks containing $400 \mathrm{~mL}$ nutrient broth $(120 \mathrm{rpm})$. The bacteria were centrifuged at $4000 \mathrm{rpm}$ for 10 minutes (MSE Minor 35, England). The supernatant was discarded. The pellet was washed twice in phosphate buffered saline (PBS) ( $\mathrm{pH} 7.2$ ). The cells were centrifuged at $4000 \mathrm{rpm}$ for 5 minutes in a preweighed tube. The supernatant was discarded and the pellet was weighed using a Kern EG balance (Kern \& Sohn, Germany). PBS containing $10 \mathrm{mM}$ sodium azide $\left(\mathrm{NaN}_{3}\right)$ was added to the tube to achieve a concentration of cells of $40 \mathrm{mg} / \mathrm{mL}$. The tube was gently inverted to disperse the cells within the PBS. Rhodamine $6 \mathrm{G}$ (R6G) to a final concentration of $10 \mu \mathrm{M}$ was immediately added and cells were incubated at $90 \mathrm{rpm}$ for 1 hour.

The cells were divided into two tubes, A and B, in the ratio of $1: 2$ but both with the same concentration of cells. Both tubes were centrifuged at $4000 \mathrm{rpm}$ for $5 \mathrm{~min}$. For tube A, the supernatant was discarded, and PBS alone was added to achieve a final concentration of cells of $40 \mathrm{mg} / \mathrm{mL}$. For tube B, the supernatant was discarded and the pellet was resuspended in PBS containing $1 \mathrm{M}$ glucose. The contents of tube $\mathrm{B}$ were then divided into five tubes, $B_{1}$ to $B_{5}$. Reserpine was added to tube $B_{1}$ to a final concentration of $60 \mathrm{ng} / \mathrm{mL}$. Tube $B_{2}$ served as a control with glucose alone. Plant extracts were added to tubes $B_{3}$ to $B_{5}$ to achieve final concentrations of $60 \mathrm{ng} / \mathrm{mL}$ of plant extract in each tube. Equal concentrations of plant extracts and reserpine were used to allow comparisons to be conducted. All of the tubes were mixed on a vortex mixer (Barnstead/Thermolyne, USA) before being incubated for 30 minutes $\left(90 \mathrm{rpm}, 37^{\circ} \mathrm{C}\right)$ in a Lab Companion SI-300 incubator.

After incubation, the tubes were centrifuged at $4000 \mathrm{rpm}$ for 10 minutes and the supernatant was discarded. The pellets were resuspended in $0.1 \mathrm{M}$ glycine $\mathrm{HCl}, \mathrm{pH}$ 3. The glycine $\mathrm{HCl}$ was used to lyse the cells. The cells were mixed on a vortex mixer before being incubated at $37^{\circ} \mathrm{C}, 90 \mathrm{rpm}$ overnight. The tubes were centrifuged at $4000 \mathrm{rpm}$ for 10 minutes and the supernatant was collected. The absorbance of R6G was measured at $527 \mathrm{~nm}$. The standards were prepared by diluting $\mathrm{R} 6 \mathrm{G}$ in glycine $\mathrm{HCl}$, and the concentrations used ranged from $0 \mu \mathrm{M}$ to $5 \mu \mathrm{M}$. 
TABLE 1: Zones of inhibition produced after exposure of bacteria to plant extracts and antibiotics. The zone of inhibition refers to the diameter of the circle in which no growth of cells was observed, minus the diameter of the filter paper disk (6 mm). The assay was conducted twice.

\begin{tabular}{lcc}
\hline Plant extract/antibiotic & B. cereus zone of inhibition $(\mathrm{mm})$ & E. coli zone of inhibition $(\mathrm{mm})$ \\
\hline C. welwitschii leaf methanol & $2.5 \pm 0.6$ & $1.3 \pm 0.5$ \\
C. welwitschii leaf water & 0 & 0 \\
C. welwitschii root methanol & $0.8 \pm 0.29$ & $0.5 \pm 0.0$ \\
T. welwitschii leaf methanol & $3.3 \pm 0.5$ & $2.3 \pm 0.5$ \\
T. welwitschii leaf water & 0 & 0 \\
T. welwitschii root methanol & $6 \pm 0$ & $4.5 \pm 1.2$ \\
T. welwitschii root water & $1.8 \pm 0.5$ & $2 \pm 0.6$ \\
Ampicillin & $9 \pm 0.0$ & $12 \pm 0.8$ \\
Methanol & 0 & 0 \\
Distilled water & 0 & 0
\end{tabular}

2.8. Determination of the Effect of T. welwitschii Extracts on Nucleic Acids Leakage. Propidium iodide is a dye that is capable of binding to nucleic acids. The dye is unable to enter viable cells, making it useful for determining the effects of plant extracts on bacterial membranes. B. cereus and $E$. coli cells were suspended in $0.9 \%$ saline solution $\left(\mathrm{OD}_{600}=\right.$ 1.5). The cell suspensions were exposed to plant extracts at concentrations of the MIC and double the MIC in duplicate for 10 minutes. The bacteria $(1 \mathrm{~mL})$ were centrifuged for 1 minute at $11000 \times \mathrm{g}$ (Centrifuge 5415C, Eppendorf, Berlin, Germany). The pellet was washed with $1 \mathrm{~mL} 0.9 \%$ saline solution. Three microliters of propidium iodide was added to each sample and the solution was mixed. The samples were kept in the dark for $10 \mathrm{~min}$. Fluorescence was measured at excitation and emission wavelengths of $544 \mathrm{~nm}$ and $612 \mathrm{~nm}$, respectively, using an $f_{\max }$ microplate spectrofluorometer (Molecular Devices, Sunnyvale, USA). The controls used were nontreated cells, 3\% DMSO, 0.1\% SDS, and kanamycin.

2.9. Determination of the Effect of T. welwitschii Extracts on Protein Leakage. B. cereus and E. coli cells were suspended in $0.9 \%$ saline solution $\left(\mathrm{OD}_{600}=1.5\right)$. The cell suspensions were exposed to plant extracts at concentrations of the MIC and double the MIC. The samples were incubated at $37^{\circ} \mathrm{C}$ with shaking (120 rpm) for $120 \mathrm{~min}$. Five hundred microlitres of cell suspension was centrifuged at $7000 \mathrm{rpm}$ for $2 \mathrm{~min}$. To $50 \mu \mathrm{L}$ of the supernatant, $950 \mu \mathrm{L}$ of Coomassie brilliant blue G-250 was added to measure the protein content by Bradford's method. The colour was allowed to develop for $10 \mathrm{~min}$ before the absorbance was measured at $595 \mathrm{~nm}$ using a spectrophotometer. The controls used were kanamycin, 3\% DMSO, 0.1\% SDS, and untreated cells. Bovine serum albumin (BSA) was used as a standard to determine protein concentration.

2.10. Statistical Analysis. The one-way analysis of variance test (ANOVA) with Dunnett's Multiple Comparison Test was used to analyse the results. The values with a $p$ value of 0.05 or less were considered statistically significant. GraphPad Prism 5 for Windows (GraphPad Software Inc., San Diego, California, USA) version 5.03 was used.

\section{Results}

3.1. Determination of Antibacterial Activity Using the Disk Diffusion Method. The results of the disk diffusion assay are shown in Table 1. The zone of inhibition refers to the diameter of the zone in which no growth of bacteria was observed minus the diameter of the filter paper disk $(6 \mathrm{~mm})$. The root methanol extract from $T$. welwitschii had the largest zones of inhibition against both $B$. cereus and E. coli at $6 \mathrm{~mm}$ and $4.5 \mathrm{~mm}$, respectively. $T$. welwitschii leaf and root methanol extracts produced larger zones of inhibition against the bacteria than C. welwitschii leaf and root methanol extracts. The leaf water extracts of both C. welwitschii and T. welwitschii produced no zones of inhibition, making them the least effective extracts. Generally the zones of inhibition are larger against $B$. cereus than against $E$. coli. The ampicillin was more effective at inhibiting E. coli than $B$. cereus $(12 \mathrm{~mm}$ and $9 \mathrm{~mm}$, resp.).

3.2. Minimum Inhibitory Concentration and Minimum Bactericidal Concentration. The results of the MIC assay, shown in Table 2, show that C. welwitschii leaf and root methanol extracts were more effective against $E$. coli than B. cereus. The T. welwitschii root water and methanol extracts were more effective against $B$. cereus than E. coli. The T. welwitschii leaf methanol showed significant growth inhibitory effect against both $E$. coli and $B$. cereus with an MIC of $0.125 \mathrm{mg} / \mathrm{mL}$. All 3 antibiotics, particularly kanamycin and norfloxacin, inhibited $B$. cereus and $E$. coli at very low concentrations. B. cereus and E. coli were inhibited at $0.5 \mu \mathrm{g} / \mathrm{mL}$ and $1 \mu \mathrm{g} / \mathrm{mL}$, respectively, by kanamycin and $0.25 \mu \mathrm{g} / \mathrm{mL}$ by norfloxacin. Of the plant extracts, $T$. welwitschii leaf methanol extract had the lowest $\mathrm{MBC}$ of $>0.5 \mathrm{mg} / \mathrm{mL}$ against B. cereus and E. coli. C. welwitschii leaf and root methanol extracts and T. welwitschii root water extract were the highest at $>4 \mathrm{mg} / \mathrm{mL}$. The antibiotics had lower MICs and MBCs against $B$. cereus than $E$. coli, except norfloxacin which had the same MIC for both bacteria. Of note was that at $4 \mathrm{mg} / \mathrm{mL}$ of $C$. welwitschii root methanol extract, E. coli grew fairly well, but at $2 \mathrm{mg} / \mathrm{mL}$ the extract killed the bacteria. 
TABLE 2: MICs and MBCs of plant extracts and antibiotics against B. cereus and E. coli. The assay was conducted twice.

\begin{tabular}{|c|c|c|c|}
\hline Bacterium & Extract/antibiotic & $\mathrm{MIC}(\mathrm{mg} / \mathrm{mL})$ & $\mathrm{MBC}(\mathrm{mg} / \mathrm{mL})$ \\
\hline \multirow{8}{*}{ B. cereus } & C. welwitschii leaf methanol & 2 & $>4$ \\
\hline & C. welwitschii root methanol & 2 & $>4$ \\
\hline & T. welwitschii leaf methanol & 0.125 & $>0.5$ \\
\hline & T. welwitschii root methanol & 0.25 & $>1$ \\
\hline & T. welwitschii root water & 0.5 & $>2$ \\
\hline & Ampicillin & 0.004 & 0.008 \\
\hline & Kanamycin & 0.0005 & 0.004 \\
\hline & Norfloxacin & 0.00025 & 0.002 \\
\hline \multirow{8}{*}{ E. coli } & C. welwitschii leaf methanol & 0.5 & 2 \\
\hline & C. welwitschii root methanol & 1 & a \\
\hline & T. welwitschii leaf methanol & 0.125 & $>0.5$ \\
\hline & T. welwitschii root methanol & 0.5 & 2 \\
\hline & T. welwitschii root water & $>4$ & $>4$ \\
\hline & Ampicillin & 0.008 & 0.016 \\
\hline & Kanamycin & 0.001 & 0.008 \\
\hline & Norfloxacin & 0.00025 & 0.004 \\
\hline
\end{tabular}

The > indicates that the MIC and MBC were higher than the tested concentrations.

${ }^{a}$ At $4 \mathrm{mg} / \mathrm{mL}$ of the C. welwitschii root methanol extract, E. coli cells were able to grow, but they were unable to grow at $2 \mathrm{mg} / \mathrm{mL}$.

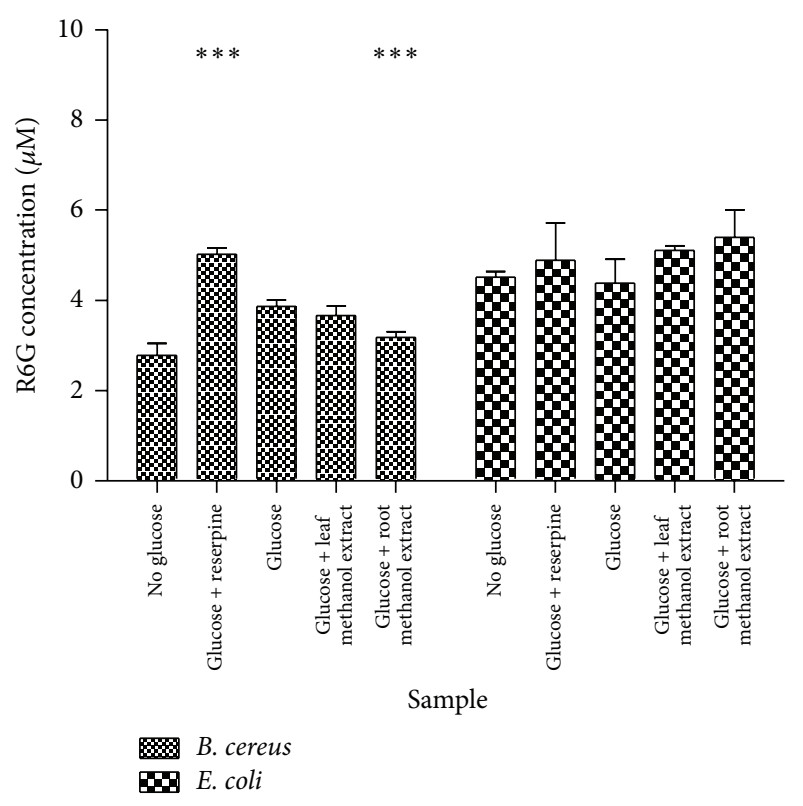

(a)

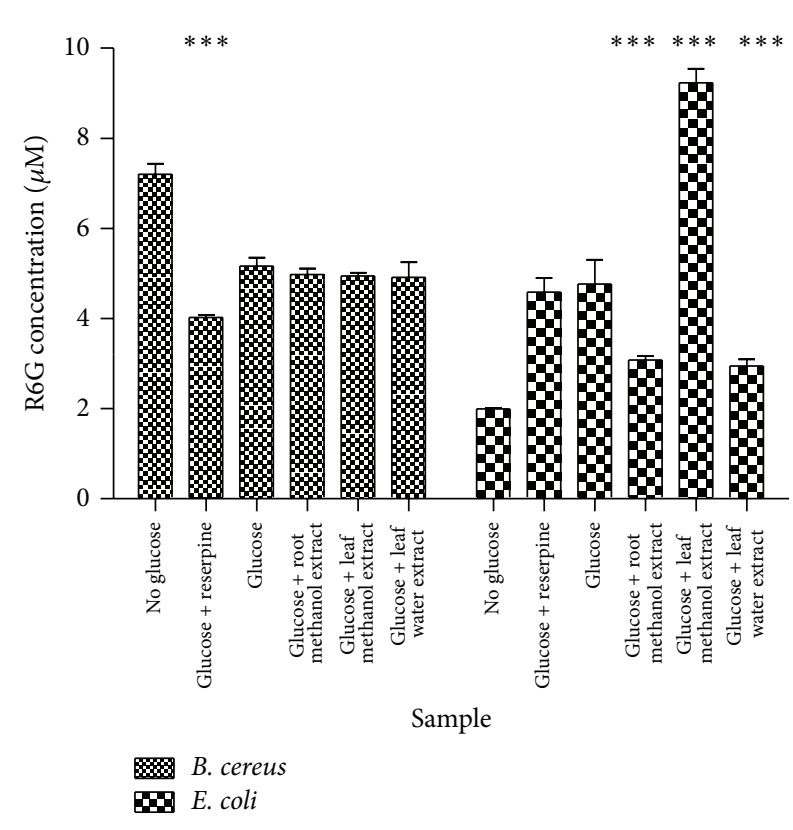

(b)

Figure 1: Drug accumulation in B. cereus and E. coli cells. The graphs show the accumulation of R6G in B. cereus and E. coli cells after exposure to T. welwitschii (a) and C. welwitschii (b) extracts. The amount of R6G accumulated is measured in $\mu \mathrm{M}$. The mean and standard deviation are shown. $n=3$. The test was conducted three times. The test for significance was carried out by comparing glucose + reserpine/plant extracts to glucose only. ${ }^{* * *} P<0.001$.

3.3. Effects of Plant Extracts on Drug Accumulation. The results of the R6G accumulation assay using T. welwitschii extracts are shown in Figure 1(a). Generally more drug accumulation was observed in $E$. coli $(>4 \mu \mathrm{M})$ than in $B$. cereus $(<4 \mu \mathrm{M})$. In the presence of the leaf methanol and root methanol extracts $5.10 \mu \mathrm{M}$ and $5.39 \mu \mathrm{M}$ R6G, respectively, accumulated in $E$. coli, while in the presence of reserpine
$4.89 \mu \mathrm{M}$ R6G was accumulated. For E. coli none of these results were significantly higher than the control: cells exposed to glucose only $(4.38 \mu \mathrm{M})$. When the $B$. cereus cells were exposed to reserpine, 5.01 $\mu \mathrm{M}$ R6G was accumulated in the cells. There was a significant decrease in R6G accumulation when $B$. cereus cells were exposed to the T. welwitschii root methanol extract. 

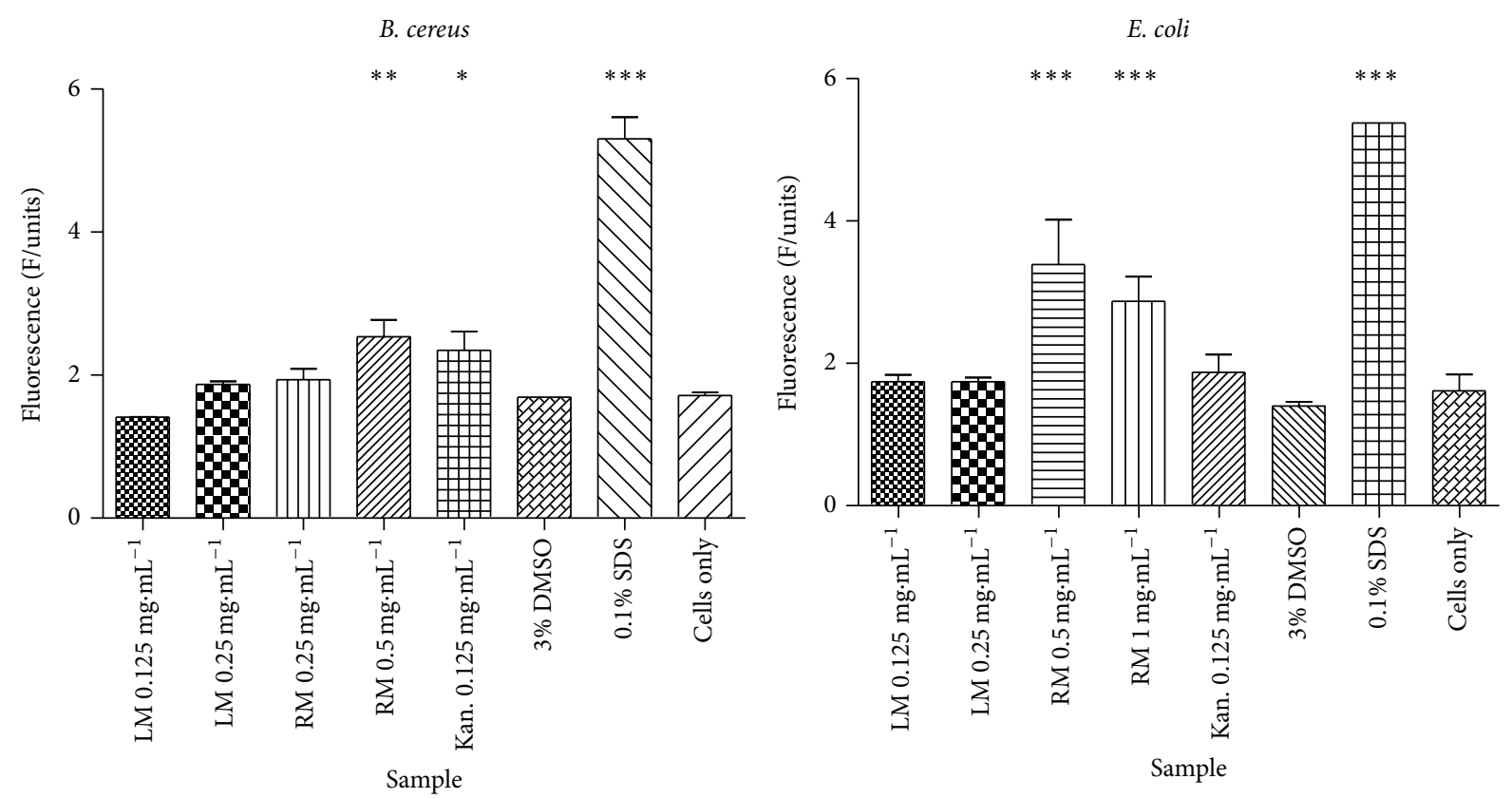

FIGURE 2: Fluorescence of nucleic acid binding propidium iodide after exposure of B. cereus and E. coli to T. welwitschii plant extracts. The T. welwitschii extracts were tested at the MIC and 2-fold the MIC, while kanamycin, $3 \%$ DMSO, $0.1 \%$ SDS, and untreated cells were used as controls. $n=2$. The test was conducted twice. The test for significance was carried out by comparing all samples to cells only. ${ }^{*} P<0.05$. ${ }^{* *} P<0.01 .{ }^{* * *} P<0.001$. LM: leaf methanol; RM: root methanol; Kan.: kanamycin; DMSO: dimethyl sulfoxide; SDS: sodium dodecyl sulphate.

Figure 1(b) shows the accumulation in B. cereus and $E$. coli after exposure to C. welwitschii extracts. In E. coli, the leaf methanol extract caused the accumulation of large amounts of R6G $(9.25 \mu \mathrm{M})$. The remaining C. welwitschii extracts, the root methanol and leaf water extracts, caused much less accumulation at $3.06 \mu \mathrm{M}$ and $2.93 \mu \mathrm{M}$, respectively, than the control cells that were exposed to glucose. In E. coli, more R6G accumulated inside the cells treated with glucose than in those treated without glucose $(4.65 \mu \mathrm{M}$ and $1.98 \mu \mathrm{M}$, resp.). In B. cereus, C. welwitschii extracts caused more drug accumulation than that observed in cells treated with reserpine, but the accumulation was not significantly different to cells exposed to glucose only. The root methanol, leaf methanol,and leaf water extracts caused the accumulation of $4.98 \mu \mathrm{M}, 4.95 \mu \mathrm{M}$, and $4.92 \mu \mathrm{M}$ R6G, while reserpine caused the accumulation of $4.03 \mu \mathrm{M}$. The cells exposed to glucose had more accumulation of R6G than those without glucose.

\subsection{Determination of the Effect of T. welwitschii Extracts} on Nucleic Acids Leakage. The fluorescence of propidium iodide in B. cereus and E. coli cells after exposure to the T. welwitschii leaf methanol and root methanol extracts is shown in Figure 2. Against B. cereus, the fluorescence of propidium iodide increased as the concentration of the root methanol extract increased. The root methanol extract caused the most nucleic acids leakage. At the MIC $(0.25 \mathrm{mg} / \mathrm{mL})$ and double the MIC $(0.5 \mathrm{mg} / \mathrm{mL})$, the fluorescence of propidium iodide was 1.94 fluorescence units (F/units) and $2.53 \mathrm{~F} /$ units, respectively. The fluorescence at $0.5 \mathrm{mg} / \mathrm{mL}$ was significantly higher than the fluorescence of propidium iodide in the untreated $B$. cereus cells, which was $1.72 \mathrm{~F} /$ units.
In E. coli, following exposure to the leaf methanol extract, the fluorescence of propidium iodide was $1.741 \mathrm{~F} /$ units and $1.743 \mathrm{~F} / \mathrm{units}$ after exposure to the MIC $(0.125 \mathrm{mg} / \mathrm{mL})$ and double the MIC $(0.25 \mathrm{mg} / \mathrm{mL})$, respectively. The root methanol extract at $0.5 \mathrm{mg} / \mathrm{mL}$ and $1 \mathrm{mg} / \mathrm{mL}$ (MIC and double the MIC, resp.) caused nucleic acid leakage in $E$. coli cells. However, as the concentration of plant extracts increased, the fluorescence of propidium iodide decreased: $3.386 \mathrm{~F} /$ units at the MIC and 2.871 F/units at 2-fold the MIC. Untreated E. coli cells had a propidium iodide fluorescence of $1.61 \mathrm{~F} /$ units. SDS was able to cause nucleic acid leakage in $B$. cereus and E. coli. In B. cereus the fluorescence of propidium iodide in cells exposed to DMSO was $1.692 \mathrm{~F} /$ units which was similar to that in untreated cells. The same was true for $E$. coli cells, where the fluorescence of propidium iodide was $1.403 \mathrm{~F} / \mathrm{units}$ for cells treated with DMSO.

3.5. Determination of the Effect of T. welwitschii Extracts on Protein Leakage. In B. cereus cells the T. welwitschii extracts do not cause protein leakage (Figure 3 ). In the presence of the plant extracts, less protein is lost compared to untreated cells. The root methanol extract at $0.25 \mathrm{mg} / \mathrm{mL}$ and $0.5 \mathrm{mg} / \mathrm{mL}$ (the MIC and double the MIC, resp.) caused significantly less protein leakage than the untreated cells. Ampicillin caused the leakage of large amounts of protein $(0.073 \mathrm{mg} / \mathrm{mL})$. In the cells treated with SDS, $0.46 \mathrm{mg} / \mathrm{mL}$ of protein was leaked, while in those treated with DMSO $0.057 \mathrm{mg} / \mathrm{mL}$ of protein was leaked out. These amounts were similar to the untreated cells: $0.052 \mathrm{mg} / \mathrm{mL}$ of protein was leaked from the cells.

In E. coli (Figure 3), the root methanol extract caused protein leakage at $1 \mathrm{mg} / \mathrm{mL}$ (double the MIC): $0.048 \mathrm{mg} / \mathrm{mL}$. 

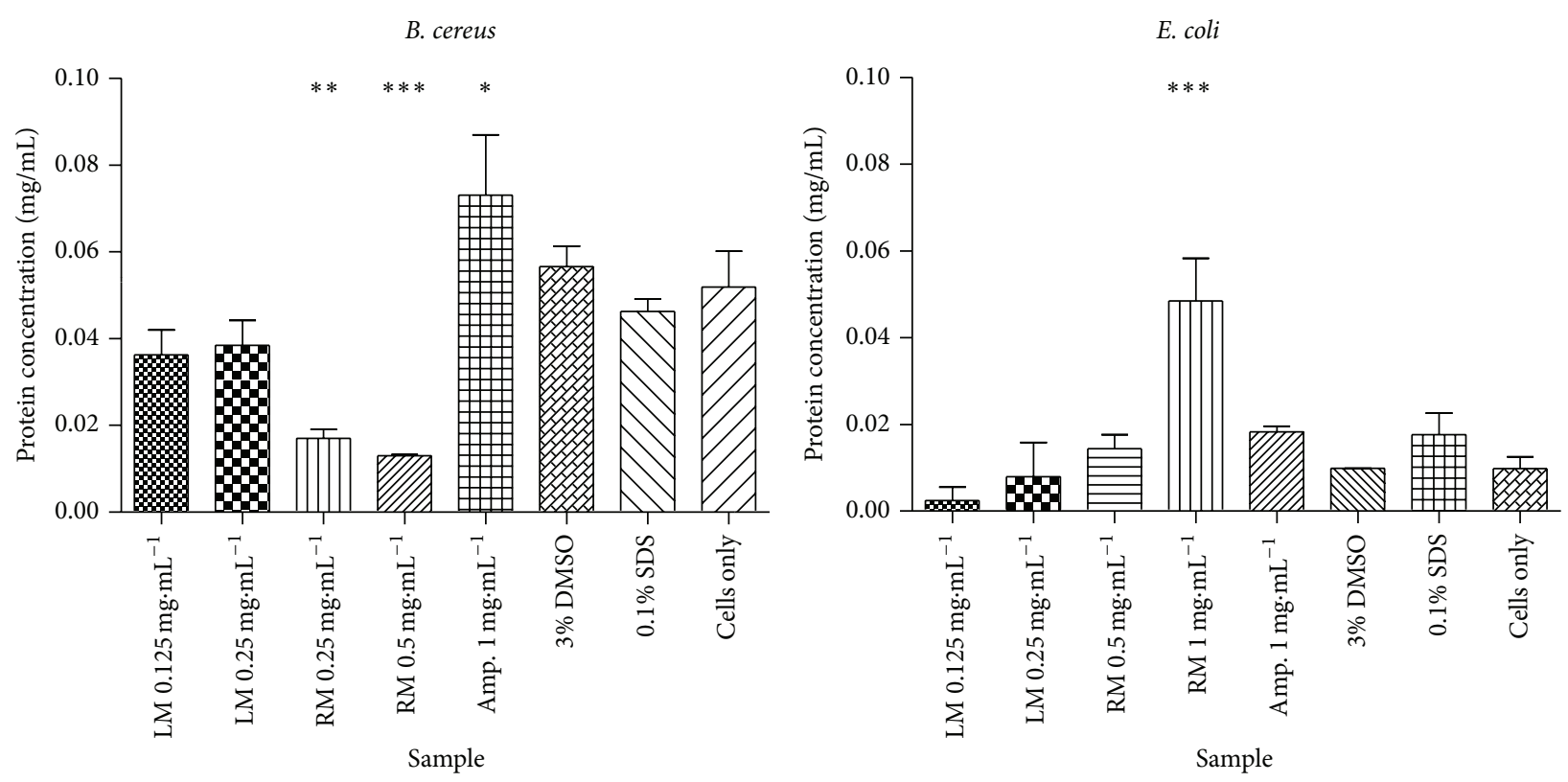

Figure 3: Graph of protein leakage in B. cereus and E. coli after exposure to the T. welwitschii leaf and root methanol extracts. The protein concentration is shown in $\mathrm{mg} / \mathrm{mL} . n=2$. The test was conducted three times. The test for significance was carried out by comparing all samples to cells only. ${ }^{*} P<0.05 .{ }^{* *} P<0.01 .{ }^{* * *} P<0.001$. LM: leaf methanol; RM: root methanol; Amp.: ampicillin; DMSO: dimethyl sulfoxide; SDS: sodium dodecyl sulphate.

The protein leakage observed in the untreated cells was $0.0098 \mathrm{mg} / \mathrm{mL}$. DMSO did not change the amount of protein leakage in B. cereus cells.

\section{Discussion}

The search for new antimicrobial agents has been necessitated by the increase in antimicrobial resistance in recent years. Fifty thousand people die every day worldwide due to infectious diseases [33]. Natural plant products are a good source of new antimicrobials as they generally have low toxicity, cause minimal environmental pollution, have a low risk of development of resistance by pathogens [34], are cheap, and are generally safer than synthetic medicines [35]. The use of known medicinal plants is advantageous as they have been prescreened over thousands of years, resulting in a higher probability of isolating useful and safe compounds from them than from plants not in use by humans already [36]. Plant materials are either present in or have provided models for approximately $50 \%$ of drugs [35]. Screening T. welwitschii and C. welwitschii for antibacterial activity was more likely to be successful as these plants are already used for medicinal purposes.

The extracts from the two plants were generally more effective against $B$. cereus than E. coli. B. cereus is a Grampositive bacterium while E. coli is Gram-negative, suggesting that the plant extracts are more effective against Grampositive than Gram-negative bacteria. According to the literature, plant extracts are generally more active against Grampositive than Gram-negative bacteria [37]. Gram-negative bacteria are more resistant to antibacterial agents than Grampositive bacteria $[38,39]$ because of the presence of the outer membrane that acts as a permeability barrier [38]. Seasotiya and Dalal [40] and Narayan [38] found that Gram-positive bacteria were more susceptible to the tested plant extracts than Gram-negative bacteria.

The MBC test results showed that when exposed to $4 \mathrm{mg} / \mathrm{mL}$ of $C$. welwitschii root methanol extract, E. coli grew fairly well, but at $2 \mathrm{mg} / \mathrm{mL}$ the extract killed the bacteria. The anomalous result observed may have been caused by high levels of nutrients present in the tuber that allowed the bacteria to overcome any bactericidal substances in the root extract. Nutrients would be more concentrated at $4 \mathrm{mg} / \mathrm{mL}$ compared to lower concentrations.

All of the plant extracts except the T. welwitschii root water extract against $E$. coli were able to inhibit the growth of the bacteria. Many studies have shown that plant extracts have antibacterial activity. Plants found to have antibacterial activity include Leonotis nepetifolia [38], Melia azedarach [21], Avicenna marina [35], L. erythrorhizon [19], Adansonia digitata, Tamarindus indica, Aframomum alboviolaceum, and Ocimum gratissimum [41].

The plant extracts had much higher MICs and MBCs than those produced by the antibiotics against the bacteria, showing that they are not as effective as the antibiotics. The use of whole extracts as opposed to purified compounds may be responsible. There may have been a lack of specificity as there were many compounds working together at reduced concentrations. Interactions between these compounds may also reduce the effectiveness of the plant extract. Studies have shown that plant extracts, though effective against bacteria, are in most cases not as effective as antibiotics [9, 36, 42-44].

The presence of efflux pumps on the bacterial membrane causes resistance in bacteria [45]. Bacteria use these efflux 
pumps to expel antibiotics from the cell until their concentration is too low to be effective against the bacteria [46]. The extracts from $T$. welwitschii caused accumulation of more R6G in E. coli cells than in B. cereus cells. T. welwitschii was more capable of binding to the efflux pumps on E. coli than those on B. cereus. However, T. welwitschii failed to cause significant drug accumulation in both bacteria.

C. welwitschii in $B$. cereus was ineffective as an efflux pump inhibitor. The $C$. welwitschii leaf methanol extract was a more effective efflux pump inhibitor in $E$. coli than reserpine. The $C$. welwitschii leaf methanol extract has potential for use as an efflux pump inhibitor. R6G was expected to accumulate in the bacterial cells in the absence of glucose while efflux of R6G would occur in the cells exposed to glucose. R6G may not have accumulated without glucose as cells may use proton driven antiporters and/or ATP driven (ATP-binding cassette $(A B C))$ transporters to expel drugs [12]. The R6G may have been expelled from the cells through the proton driven antiporters as opposed to the ABC transporters. E. coli has 19 antiporters belonging to the major facilitator superfamily, small multidrug resistance family and the resistance/nodulation/cell division family [12], and 80 ABC transporter proteins [47]. Proton driven antiporters expel drugs by coupling drug efflux to the influx of a proton, $\mathrm{H}^{+}$, while ABC transporters couple drug efflux to the hydrolysis of ATP [12]. The AcrAB-TolC pump is a member of the resistancenodulation-cell division (RND) family of tripartite multidrug efflux pumps ubiquitous throughout Gram-negative bacteria [48]. In E. coli, the multidrug efflux pump has been shown to expel a wide range of antibacterial agents [48].

Many plant extracts with the ability to promote drug accumulation in bacterial cells have been studied. Artemisia absinthium has been found to contain efflux pump inhibitory compounds [11]. Hydrastis canadensis, Curcuma longa, Capsicum annum, and Elettaria cardamomum have been found to inhibit efflux pump activity [40, 49].

Some compounds are capable of disrupting the integrity of the bacterial cell wall/membrane; for example, polymyxins increase bacterial membrane permeability and lipopeptides like daptomycin and crystallomycin bind to bacteria and cause rapid depolarisation of the bacterial membrane and eventual cell death [50]. The $T$. welwitschii root methanol extract was capable of causing damage to the B. cereus and $E$. coli membranes resulting in nucleic acid leakage (Figure 2). DMSO did not cause damage to the bacterial membranes as the protein and nucleic acid leakage from the bacterial cells did not change significantly when the cells were exposed to DMSO. Although the root methanol extract caused leakage of nucleic acids in E. coli, the leakage decreased with increasing concentration of plant extracts. Further studies are needed to determine the cause of this phenomenon. Cocos nucifera husk extracts caused leakage of nucleic acids in bacteria [51]. Plumbago zeylonica, Leucas aspera, and Hemidesmus indicus were all found to be capable of causing nucleic acid leakage in bacteria [52]. The plant extracts from these plants were found to contain phenols and flavonoids, resulting in the authors concluding that the membrane disrupting activities of the extracts may be due to the activities of these phytochemicals [52].
Ampicillin was able to cause significant protein leakage in $B$. cereus but not in E. coli. Ampicillin inhibits bacterial cell wall synthesis [1]. Ampicillin is thus expected to be more effective against Gram-positive bacteria than Gram-negative bacteria due to the differences in their structures. Grampositive bacteria have thick cell walls $(20-80 \mathrm{~nm})$ composed mainly of peptidoglycan while Gram-negative bacteria have thin, inner peptidoglycan layers $(2-7 \mathrm{~nm})$ and an outer membrane $(7-8 \mathrm{~nm})$ of lipid, protein, and lipopolysaccharide $[1]$.

Protein leakage was only observed in E. coli after treatment with $1 \mathrm{mg} / \mathrm{mL}$ T. welwitschii root methanol extract. The root methanol extract was able to bind to and disrupt the $E$. coli membrane and not the $B$. cereus cell wall. Some authors have found that plant extracts are capable of causing membrane disruption $[53,54]$. Henie et al. [53] found that Psidium guajava was capable of causing protein leakage in various bacteria, while Akinpelu et al. [55] found that extracts from Garcinia kola caused protein leakage in bacteria, including $E$. coli.

\section{Conclusions}

In conclusion, the leaf and root extracts of $C$. welwitschii and $T$. welwitschii were shown to have antibacterial activity against $B$. cereus and E. coli. T. welwitschii extracts were more potent growth inhibitory activity against the bacteria than the $C$. welwitschii extracts. Further analysis is needed to investigate the exact mode of activity of the plant extracts and the in vivo toxicity of the plant extracts and to determine the phytoconstituents present in the plant extracts. T. welwitschii may be a potential source of antibacterial agents.

\section{Disclosure}

Batanai Moyo is co-author.

\section{Conflict of Interests}

The authors declare that there is no conflict of interests regarding the publication of this paper.

\section{Authors' Contribution}

Batanai Moyo performed the experiments, analysed and interpreted the results obtained, and wrote the document. Stanley Mukanganyama directed the study, obtained the plant material used, analysed and interpreted the results, and edited the paper. All authors have read and approved of the paper.

\section{Acknowledgments}

The authors would like to acknowledge Mr. Christopher Chapano from the National Botanical and Herbarium Garden, Harare, who identified C. welwitschii and T. welwitschii var. welwitschii. They would like to thank Mr. Noel Mukanganyama, a herbalist from Centenary, Zimbabwe, who 
showed them the C. welwitschii plant and provided information on ethnomedicinal uses. This work was supported by the IPICS-ZIM01 project from the International Program in the Chemical Sciences (IPICS, Uppsala University, Sweden), and the International Foundation for Science (IFS F/3413-03), Stockholm, Sweden.

\section{References}

[1] J. M. Wiley, L. M. Sherwood, and C. J. Woolverton, Prescott, Harley, and Klein's Microbiology, McGraw-Hill, New York, NY, USA, 7th edition, 2008.

[2] B. Spellberg, R. Guidos, D. Gilbert et al., "The epidemic of antibiotic-resistant infections: a call to action for the medical community from the Infectious Diseases Society of America," Clinical Infectious Diseases, vol. 46, no. 2, pp. 155-164, 2008.

[3] Infectious Diseases Society of America, Bad Bugs No Drugs, 2004, http://www.idsociety.org/uploadedFiles/IDSA/Policy_and_ Advocacy/Current_Topics_and_Issues/Antimicrobial_Resistance/10x20/Images/Bad\%20Bugs\%20no\%20Drugs.pdf.

[4] A. Parisien, B. Allain, J. Zhang, R. Mandeville, and C. Q. Lan, "Novel alternatives to antibiotics: Bacteriophages, bacterial cell wall hydrolases, and antimicrobial peptides," Journal of Applied Microbiology, vol. 104, no. 1, pp. 1-13, 2008.

[5] T. Sibanda and A. I. Okoh, "In vitro evaluation of the interactions between acetone extracts of Garcinia kola seeds and some antibiotics," African Journal of Biotechnology, vol. 7, no. 11, pp. 1672-1678, 2008.

[6] S. E. Cosgrove and Y. Carmeli, "The impact of antimicrobial resistance on health and economic outcomes," Clinical Infectious Diseases, vol. 36, no. 11, pp. 1433-1437, 2003.

[7] G. G. F. Nascimento, J. Locatelli, P. C. Freitas, and G. L. Silva, "Antibacterial activity of plant extracts and phytochemicals on antibiotic-resistant bacteria," Brazilian Journal of Microbiology, vol. 31, no. 4, pp. 247-256, 2000.

[8] J. C. N. Assob, H. L. F. Kamga, D. S. Nsagha et al., "Antimicrobial and toxicological activities of five medicinal plant species from Cameroon Traditional Medicine," BMC Complementary and Alternative Medicine, vol. 11, article 70, 2011.

[9] S. T. Lacmata, V. Kuete, J. P. Dzoyem et al., "Antibacterial activities of selected Cameroonian plants and their synergistic effects with antibiotics against bacteria expressing MDR phenotypes," Evidence-Based Complementary and Alternative Medicine, vol. 2012, Article ID 623723, 11 pages, 2012.

[10] F. C. Tenover, "Mechanisms of antimicrobial resistance in bacteria," The American Journal of Medicine, vol. 119, no. 6, pp. S3-S10, 2006.

[11] Y. C. Fiamegos, P. L. Kastritis, V. Exarchou et al., "Antimicrobial and efflux pump inhibitory activity of caffeoylquinic acids from Artemisia absinthium against Gram-positive pathogenic bacteria," PLoS ONE, vol. 6, no. 4, Article ID e18127, 12 pages, 2011.

[12] M. I. Borges-Walmsley, K. S. McKeegan, and A. R. Walmsley, "Structure and function of efflux pumps that confer resistance to drugs," Biochemical Journal, vol. 376, no. 2, pp. 313-338, 2003.

[13] M. Stavri, L. J. V. Piddock, and S. Gibbons, "Bacterial efflux pump inhibitors from natural sources," Journal of Antimicrobial Chemotherapy, vol. 59, no. 6, pp. 1247-1260, 2007.

[14] World Health Organization, "Traditional medicine," 2003, http://www.who.int/mediacentre/factsheets/2003/fs134/en/.
[15] World Health Organisation, Biodiversity, 2014, http://www.who .int/globalchange/ecosystems/biodiversity/en/index.htmL.

[16] M. Obeidat, "Antimicrobial activity of some medicinal plants against multidrug resistant skin pathogens," Journal of Medicinal Plants Research, vol. 5, no. 16, pp. 3856-3860, 2011.

[17] Z. K. Shinwari, I. Khan, S. Naz, and A. Hussain, "Assessment of antibacterial activity of three plants used in Pakistan to cure respiratory diseases," African Journal of Biotechnology, vol. 8, no. 24, pp. 7082-7086, 2009.

[18] M. R. S. Zaidan, A. Noor Rain, A. R. Badrul, A. Adlin, A. Norazah, and I. Zakiah, "In vitro screening of five local medicinal plants for antibacterial activity using disc diffusion method," Tropical Biomedicine, vol. 22, no. 2, pp. 165-170, 2005.

[19] M. J. Giner, S. Vegara, L. Funes et al., "Antimicrobial activity of food-compatible plant extracts and chitosan against naturally occurring micro-organisms in tomato juice," Journal of the Science of Food and Agriculture, vol. 92, no. 9, pp. 1917-1923, 2012.

[20] K. Konaté, A. Hilou, J. F. Mavoungou et al., "Antimicrobial activity of polyphenol-rich fractions from Sida alba L. (Malvaceae) against co-trimoxazol-resistant bacteria strains," Annals of Clinical Microbiology and Antimicrobials, vol. 11, article 5, 6 pages, 2012.

[21] A. V. Khan, Q. U. Ahmed, M. R. Mir, I. Shukla, and A. A. Khan, "Antibacterial efficacy of the seed extracts of Melia azedarach against some hospital isolated human pathogenic bacterial strains," Asian Pacific Journal of Tropical Biomedicine, vol. 1, no. 6, pp. 452-455, 2011.

[22] R. M. Darwish and T. A. Aburjai, "Effect of ethnomedicinal plants used in folklore medicine in Jordan as antibiotic resistant inhibitors on Escherichia coli," BMC Complementary and Alternative Medicine, vol. 10, article 9, 2010.

[23] T. A. Chitemerere and S. Mukanganyama, "In vitro activity of selected medicinal plants from Zimbabwe," The African Journal of Plant Science and Biotechnology, vol. 5, no. 1, pp. 1-7, 2011.

[24] E. Rukangira, "The African herbal industry: constraints and challenges," 2001, http://www.academia.edu/3443773/The_African_herbal_industry_constraints_and_challenges.

[25] Encyclopaedia Britannica, "Cissus," 2014, http://www.britannica .com/EBchecked/topic/118662/Cissus.

[26] Conservatoire et Jardin Botaniques, Cissus welwitschii (Baker) Planch, 2007, http://www.ville-ge.ch/musinfo/bd/cjb/africa/details.php?langue $=$ an\&id $=123890$.

[27] JSTOR Plant Science, "Entry for Cissus welwitschii Bak. Planch. [family VITACEAE]," 2014, http://plants.jstor.org/flora/fz1626.

[28] Flora of Zimbabwe, “Triumfetta welwitschii Mast," 2014, http:// www.zimbabweflora.co.zw/speciesdata/species.php?species_id= 138780.

[29] C. Long, Swaziland's Flora-siSwati Names and Uses, 2005, http://www.sntc.org.sz/flora/clusagelist.asp?uid=2\&pg=46.

[30] D. G. Fowler, "Traditional fever remedies: a list of Zambian plants," 2006, http://www.giftsofhealth.org/ritam/news/Traditional_Fever_remediel.doc.

[31] J. N. Eloff, "A sensitive and quick microplate method to determine the minimal inhibitory concentration of plant extracts for bacteria," Planta Medica, vol. 64, no. 8, pp. 711-713, 1998.

[32] T. L. Riss, R. A. Moravec, A. L. Niles, H. A. Benink, T. J. Worzella, and L. Minor, Cell Viability Assays, 2015, http://www.ncbi.nlm .nih.gov/books/NBK144065/pdf/mttassays.pdf.

[33] World Health Organization, Infectious Diseases Kill over 17 Million People a Year: WHO Warns of Global Crisis, WHO, 2015, http://www.who.int/whr/1996/media_centre/press_release/en/. 
[34] E. R. Mbega, C. N. Mortensen, R. B. Mabagala, and E. G. Wulff, "The effect of plant extracts as seed treatments to control bacterial leaf spot of tomato in Tanzania," Journal of General Plant Pathology, vol. 78, no. 4, pp. 277-286, 2012.

[35] S. Ravikumar, M. S. A. Ali, and M. Ferosekhan, "Antibacterial activity of chosen mangrove plants against bacterial specified pathogens," World Applied Sciences Journal, vol. 14, no. 8, pp. 1198-1202, 2011.

[36] T. R. H. Nielsen, V. Kuete, A. K. Jäger, J. J. M. Meyer, and N. Lall, "Antimicrobial activity of selected South African medicinal plants," BMC Complementary and Alternative Medicine, vol. 12, article 74, 2012.

[37] R. Nalubega, J. D. Kabasa, D. Olila, and J. Kateregga, "Evaluation of antibacterial activity of selected ethnomedicinal plants for poultry in Masaka District, Uganda," Research Journal of Pharmacology, vol. 5, no. 2, pp. 18-21, 2011.

[38] S. S. Narayan, "Antibacterial potential of crude methanolic extract of Leonotis nepretifolia (L) R. Br," International Research Journal of Pharmacy, vol. 3, no. 2, pp. 277-278, 2012.

[39] A. D. Russel, "Bacterial resistance to disinfectants," British Journal of Infection Control, vol. 3, no. 3, pp. 22-24, 2002.

[40] L. Seasotiya and S. Dalal, "Screening of Indian medicinal plants as efflux pump inhibitors of fluoroquinolones," Journal of Pharmacognosy and Phytochemistry, vol. 3, no. 1, pp. 235-241, 2014.

[41] D. E. Djeussi, J. A. K. Noumedem, J. A. Seukep et al., "Antibacterial activities of selected edible plants extracts against multidrug-resistant Gram-negative bacteria," BMC Complementary and Alternative Medicine, vol. 13, article 164, 2013.

[42] A. M. El-Mahmood, J. H. Doughari, and H. S. Kiman, "In vitro antimicrobial activity of crude leaf and stem bark extracts of Gmelina arborea (Roxb) against some pathogenic species of Enterobacteriaceae," African Journal of Pharmacy and Pharmacology, vol. 4, no. 6, pp. 355-361, 2010.

[43] P. V. Karsha and O. B. Lakshmi, "Antibacterial activity of black pepper (Piper nigrum Linn.) with special reference to its mode of action on bacteria," Indian Journal of Natural Products and Resources, vol. 1, no. 2, pp. 213-215, 2010.

[44] K. Rakholiya and S. Chanda, "In vitro interaction of certain antimicrobial agents in combination with plant extracts against some pathogenic bacterial strains," Asian Pacific Journal of Tropical Biomedicine, vol. 2, no. 2, supplement, pp. S876-S880, 2012.

[45] M. I. Garvey, M. M. Rahman, S. Gibbons, and L. J. V. Piddock, "Medicinal plant extracts with efflux inhibitory activity against Gram-negative bacteria," International Journal of Antimicrobial Agents, vol. 37, no. 2, pp. 145-151, 2011.

[46] J. G. Holler, S. B. Christensen, H.-C. Slotved et al., "Novel inhibitory activity of the Staphylococcus aureus NorA efflux pump by a kaempferol rhamnoside isolated from Persea lingue Nees," Journal of Antimicrobial Chemotherapy, vol. 67, no. 5, Article ID dks005, pp. 1138-1144, 2012.

[47] G. Kaul and G. Pattan, "MsbA ATP-binding cassette (ABC) transporter of E. coli: structure and possible flippase mechanism," Indian Journal of Biochemistry and Biophysics, vol. 48, no. 1, pp. 7-13, 2011.

[48] T. Sibanda and A. I. Okoh, "The challenges of overcoming antibiotic resistance: plant extracts as potential sources of antimicrobial and resistance modifying agents," African Journal of Biotechnology, vol. 6, no. 25, pp. 2886-2896, 2007.

[49] K. A. Ettefagh, J. T. Burns, H. A. Junio, G. W. Kaatz, and N. B. Cech, "Goldenseal (Hydrastis canadensis L.) extracts synergistically enhance the antibacterial activity of berberine via efflux pump inhibition," Planta Medica, vol. 77, no. 8, pp. 835-840, 2011.

[50] P. Sumthong and R. Verpoorte, "Developing antimicrobial compounds from natural sources," 2007, https://openaccess.leidenuniv.nl/bitstream/handle/1887/12086/02.pdf? sequence $=17$.

[51] D. A. Akinpelu, K. A. Alayande, O. A. Aiyegoro, O. F. Akinpelu, and A. I. Okoh, "Probable mechanisms of biocidal action of Cocos nucifera Husk extract and fractions on bacteria isolates," BMC Complementary and Alternative Medicine, vol. 15, article 116, 2015.

[52] K. Saritha, A. Rajesh, K. Manjulatha, O. H. Setty, and S. Yenugu, "Mechanism of antibacterial action of the alcoholic extracts of Hemidesmus indicus (L.) R. Br. ex Schult, Leucas aspera (Wild.), Plumbago zeylanica L., and Tridax procumbens (L.) R. Br. ex Schult," Frontiers in Microbiology, vol. 6, article 577, 2015.

[53] E. F. P. Henie, H. Zaiton, and M. Suhaila, "Bacterial membrane disruption in food pathogens by Psidium guajava leaf extracts," International Food Research Journal, vol. 16, no. 3, pp. 297-311, 2009.

[54] S. O. Oyedemi, A. I. Okoh, L. V. Mabinya, G. Pirochenva, and A. J. Afolayan, "The proposed mechanism of bactericidal action of eugenol, A-terpineol and Y-terpinene against Listeria monocytogenes, Streptococcus pyogenes, Proteus vulgaris and Escherichia coli," African Journal of Biotechnology, vol. 8, no. 7, pp. 1280-1286, 2009.

[55] D. A. Akinpelu, M. F. Adegboye, O. A. Adeloye, and A. I. Okoh, "Biocidal activity of partially purified fractions from methanolic extract of Garcinia kola (Heckel) seeds on bacterial isolates," Biological Research, vol. 41, no. 3, pp. 277-287, 2008. 

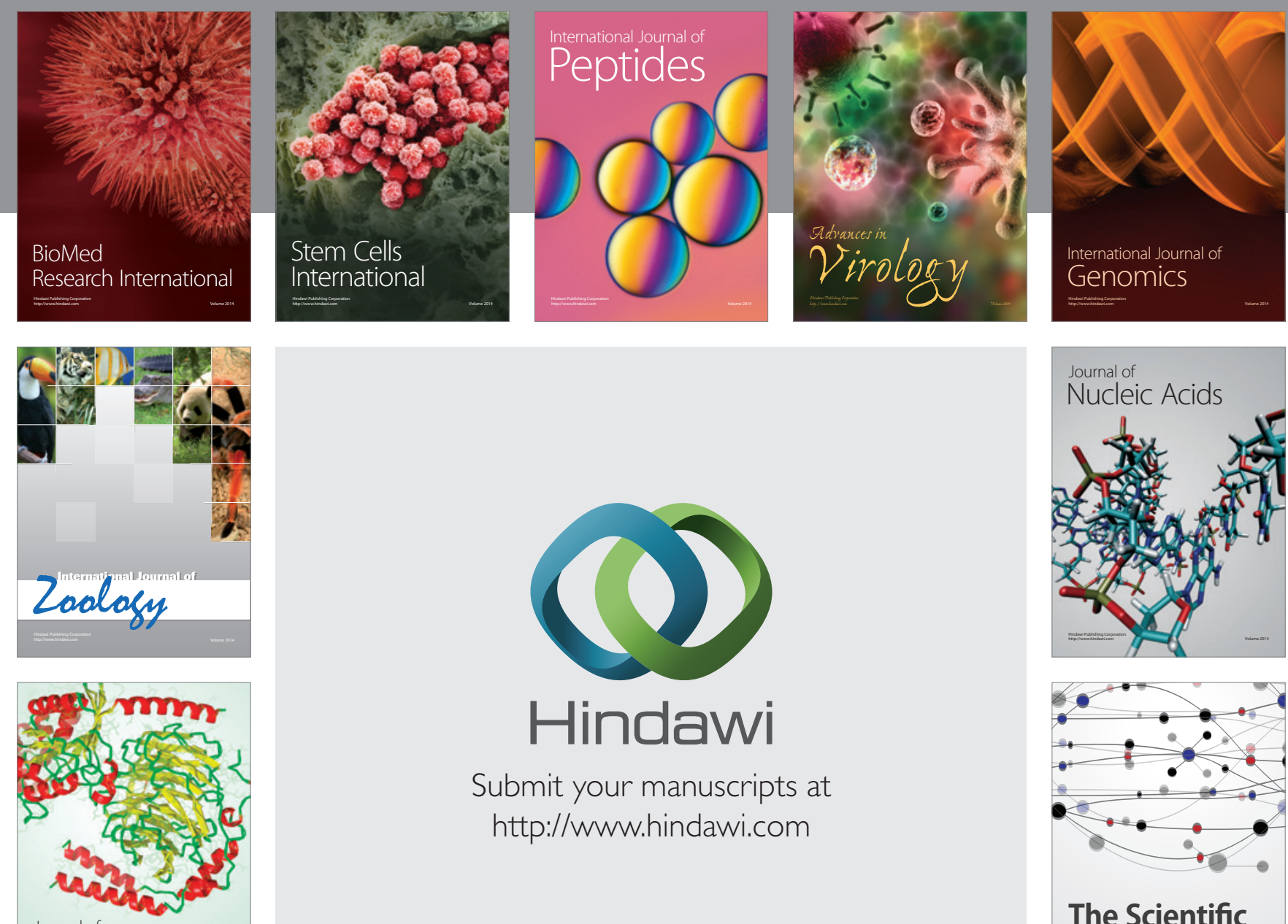

Submit your manuscripts at

http://www.hindawi.com

Journal of
Signal Transduction
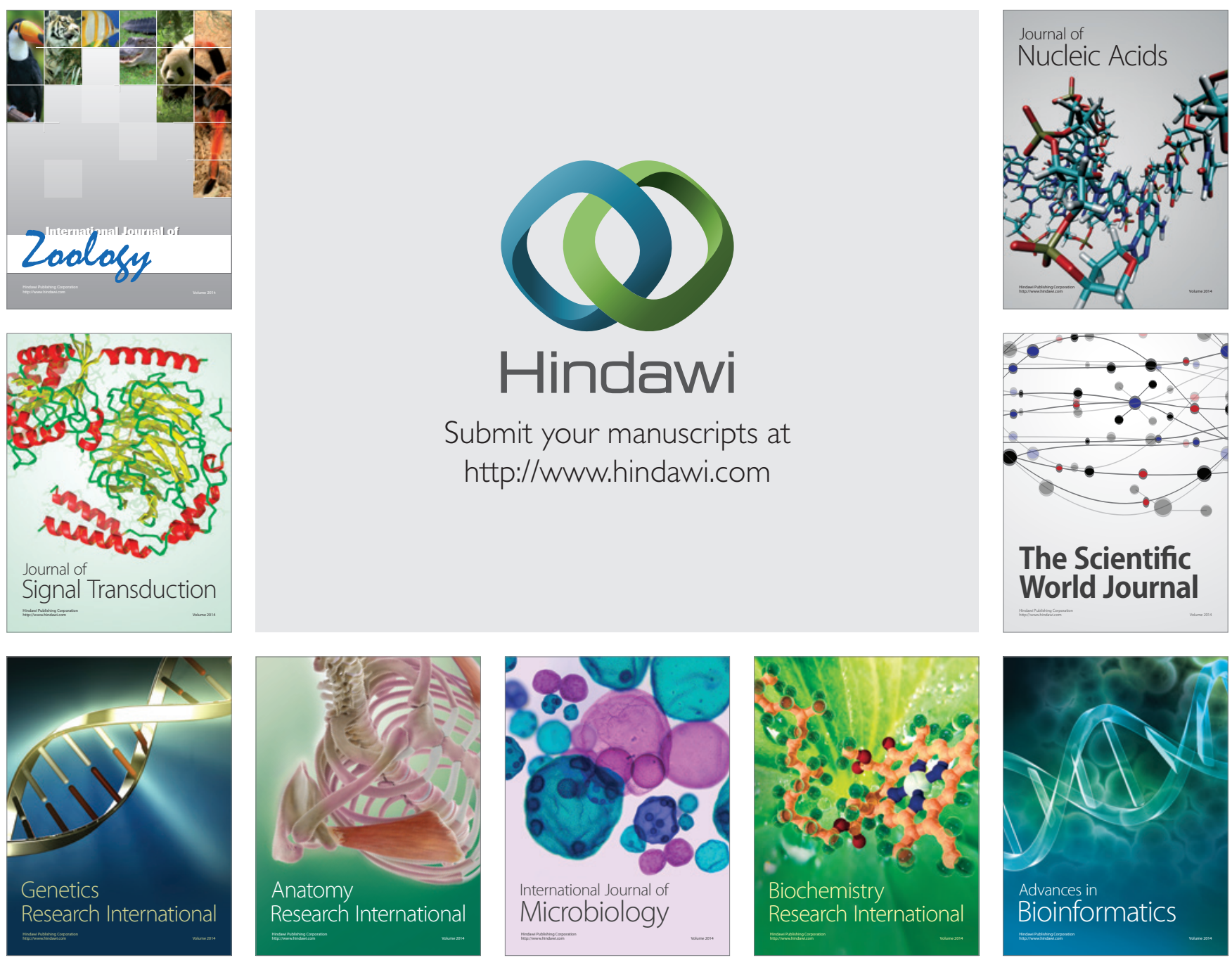

The Scientific World Journal
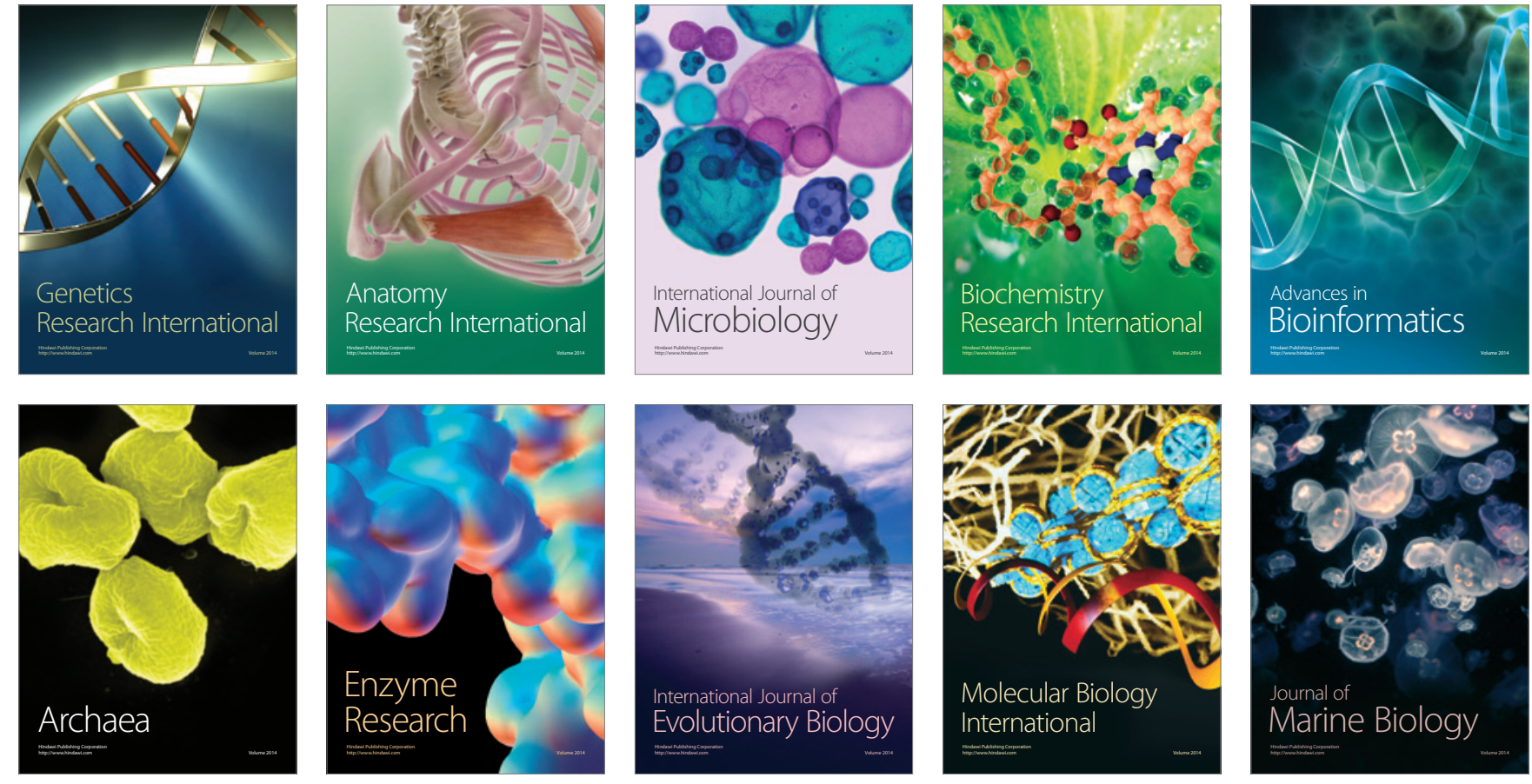